names such as Shell, Unilever, Esso, Dunlop, Courtaulds, British Petroleum and Imperial Chemical Industries, Ltd.

There are less expensive ways of recruiting in the United States. The Civil Service, CEGB and UKAEA run a shoestring operation, employing $\mathrm{Mr} \mathrm{H}$. S. Hoff to tour the US in search of expatriate scientists. What the operation loses in luxury it more than makes up for in ingenuity. Advertisements are placed in British magazines which the scientists are known to read, and - a subtle move this-in papers such as the Daily Telegraph which their parents back in Britain read. The hope is that parents will write to their sons suggesting that they come back. Mr Hoff is interested in young scientists with research fellowships in American universities, where they earn $\$ 6,000$ to $\$ 7,000$ a year, and they are offered exactly the same terms as those on which recruitment is carried out in this countrythere is no question of bribing by higher salaries, which, it is feared, would cause unrest back in Britain. Through the advertisements, and personal letters, $\mathrm{Mr}$ Hoff and his team last year interviewed about two hundred people for specific jobs, and made offers to one hundred and twenty of them. Of these about sixty accepted, a remarkably high figure for recruiting of this kind; one reason for this, Mr Hoff suggests, is English wives, who find foreign life less alluring than do their husbands.

Mr Hoff's efforts are helped by a scheme run by the Science Research Council, which awards one year studentships worth $£ l, 175$ a year in British universities. In addition to the fellowships, which are intended to give the migrants a bridgehead from which to find permanent jobs, the SRC pays fares home. Eighty applications were received last year, and about fortyfive eventually came home-the difference, presumably, made up of some who are unsuitable, and others who fell by the wayside. Another scheme is run by the Royal Institute of Chemistry, and is aimed at junior university staff, people who usually go to the United States with the firm intention of coming back. Before going, the scientists fill in a form with details of their career; companies also register with the institute, and by matching up company requirements with individuals' qualifications, it is hoped that jobs will be found. No charge is made to the chemists-who need not be members of the institute-but the companies are charged a fee of $£ 21$ for each candidate employed. If necessary, interviews can be arranged in the United States. This scheme is still in its infancy, but it fulfils the essential criterion of keeping scientists in the US in touch with opportunities at home. It may be possible to generalize the scheme to take in the other institutes (of biology, physics, mathematics and metallurgy) if financial support can be found.

The Ministry of Technology itself has two schemes, recently described in Nature $(214,549 ; 1967)$, but in contrast with other schemes, these seem aimed at higher management. The management consultants, Management Selection Group, are recruiting this kind of candidate, and have $£ 75,000$ with which to do it. Whether the more experienced managers will be easy to recruit is not yet known - on the face of it, it seems more sensible to try to recover those who are not entirely settled. As Mr Hoff puts it, "Once a young scientist marries an American. girl, we say goodbye to him for good".

\section{New Recruits?}

The Civil Service Commissioners are clearly out to demolish the notion that recruitment to the Civil Service is dominated by arts graduates from Oxford and Cambridge. In their annual report for 1966 (HMSO, 6s.) they record cheerfully that for the first time applications from universities other than Oxford and Cambridge were in the majority, although it is only fair to point out that it is still twice as easy to be successful in the examinations with an Oxbridge background. Other universities supplied 50 per cent of the candidates, but only 35 per cent of those who were successful.

As for scientists, only 10 of those recruited to the Administrative Class were scientists or mathematicians. This is to be compared with 34 historians, 13 modern linguists and 10 classicists. There was, however, an improvement in the recruitment to the Scientific Officer class, at least in the higher grades of Principal Scientific Officer and above. The annual average is about 10 , but in 1966, 43 were appointed, mainly for the Ministry of Technology. In other grades recruitment was also better, partly because of recruitment of 20 geologists for the new Institute of Geological Sciences.

\section{Cigarettes and Cancer}

WHEN the cigarette manufacturers in Britain renamed their research committee the Tobacco Research Council in 1963, they cannot clearly have foreseen how this organization would grow into an autonomous and perceptive organization for research into the connexion between smoking and cancer. The annual report of the research council describes an increasing programme of research into the chemistry, the pathology and the epidemiology of smoking which branches out, here and there, into straightforward immunology intended to throw light on the relationship between cancer production and the thymus. The scale of the council's operations is measured by the annual expenditure of $£ 750,000$. The staff now amounts to 250 , and Dr F. Dickens has now succeeded Dr T. D. Day as director of the Harrogate laboratory.

The nub of the council's own research on the carcinogenicity of smoking seems to lie in the discovery that cigarette smoke contains a stable and non-volatile ingredient which can cause skin cancers on the backs of mice. The council has developed a mouse skin assay for carcinogens over a period of several years at its Harrogate laboratory. In one series of experiments, four groups of 2,000 mice were used at quarterly intervals to compare the formation of tumours by material derived from cigarette smoke and treated in several ways. The result showed that a variety of tumours was produced and that there is a definite relationship between dose and response. Comparisons between fresh and stored condensate from cigarette smoke suggest that half the tumorigenicity of cigarette condensate kept for 24 hours is caused by neutral nonvolatile compounds. The report says that the non-volatile carcinogens in cigarette smoke are "worth serious attention" and promises that there will be an attempt to isolate them by fractionation.

On the possibility of links between cigarette smoking and various pathological conditions such as lung 